\title{
Correction: Measuring progress towards Sustainable Development Goal 3.8 on universal health coverage in Kenya
}

Barasa E, Nguhiu P, McIntyre D. Measuring progress towards Sustainable Development Goal 3.8 on universal health coverage in Kenya. BMJ Glob Health 2018;3:e000904.

In table 1, row 'THE per capita (US\$)', the values are mistakenly expressed as percentages; they should actually be expressed as absolute numbers in USD (without the $\%$ sign).

Open access This is an open access article distributed in accordance with the Creative Commons Attribution 4.0 Unported (CC BY 4.0) license, which permits others to copy, redistribute, remix, transform and build upon this work for any purpose, provided the original work is properly cited, a link to the licence is given, and indication of whether changes were made. See: https://creativecommons.org/licenses/by/4.0/.

C Author(s) (or their employer(s)) 2018. Re-use permitted under CC BY. Published by BMJ.

BMJ Glob Health 2018;3:e000904corr1. doi:10.1136/bmjgh-2018-000904corr1

(A) Check for updates 